\title{
Precore mutant hepatitis B virus-associated fulminant hepatitis during infliximab therapy for rheumatoid arthritis
}

\author{
Hiroko Kuwabara • Akira Fukuda • Yasuhiro Tsuda • \\ Yuro Shibayama
}

Received: 8 February 2010 /Accepted: 15 March 2010 / Published online: 9 April 2010

(C) The Author(s) 2010. This article is published with open access at Springerlink.com

\begin{abstract}
A 73-year-old female, who suffered from rheumatoid arthritis for 10 years, developed precore mutant hepatitis B virus-associated fulminant hepatitis after 1 year of infliximab therapy and subsequent methotrexate withdrawal. We emphasize the importance of preemptive antiviral therapy before starting infliximab administration and withdrawing immunosuppressive drugs.
\end{abstract}

Keywords Fulminant hepatitis · HBV - Infliximab · MTX . Rheumatoid arthritis

\section{Introduction}

Infliximab, a tumor necrosis factor- $\alpha$ (TNF- $\alpha$ ) inhibitor, has become the standard therapy for active rheumatoid arthritis (RA), but also has influences on bacterial, viral, and tuberculous infections [1]. In particular, the reactivation of hepatitis B virus (HBV) is problematic [2] and HBVinduced fulminant hepatitis following infliximab treatment has been reported in patients with Crohn's disease and Still's disease [3-6]. Here, we describe an autopsy case of RA who developed precore mutant HBV-associated fulminant hepatitis after 1 year of infliximab therapy and subsequent methotrexate (MTX) withdrawal.

H. Kuwabara $(\square) \cdot$ Y. Shibayama

Department of Pathology, Osaka Medical College,

2-7, Daigaku-machi,

Takatsuki, Osaka 569-8686, Japan

e-mail: pa2020@art.osaka-med.ac.jp

A. Fukuda $\cdot$ Y. Tsuda

Department of Internal Medicine, Osaka Medical College,

2-7, Daigaku-machi,

Takatsuki, Osaka 569-8686, Japan

\section{Case report}

A 73-year-old female, with a 10-year history of RA, had been treated with prednisone (5-10 $\mathrm{mg} /$ day) and MTX (5$8 \mathrm{mg} /$ week) for 10 and 6 years, respectively. These were ineffective, and infliximab (150 mg every 8 weeks, $3 \mathrm{mg} / \mathrm{kg}$ ) was added between June 2004 and May 2005, with liver function tests at each infusion. A pretreatment screening test showed that HBsAg and $\mathrm{HBcAb}$ were positive, and hepatitis $\mathrm{C}$ virus antibody was negative. Liver tests and images showed no abnormalities. MTX and prednisone were tapered, and prednisone was withdrawn in April 2005. An effective clinical improvement of joint disease was observed, and $\mathrm{C}$ reactive protein became normal. After the eighth infusion of infliximab, the liver function was found to be abnormal (AST $291 \mathrm{IU} / \mathrm{L}$ (normal <40), ALT $331 \mathrm{IU} / \mathrm{L}$ $(<40)$ ), and MTX therapy was withdrawn. Her liver function progressively worsened (AST $1690 \mathrm{IU} / \mathrm{L}$, ALT $1390 \mathrm{IU} / \mathrm{L}$ ), and she was admitted to our hospital in June 2005.

On admission, she had jaundice and mild hepatic encephalopathy. Laboratory data revealed AST 393 IU/L, ALT $544 \mathrm{IU} / \mathrm{L}, \gamma$ GTP $130 \mathrm{IU} / \mathrm{L}(<30)$, LDH $364 \mathrm{IU} / \mathrm{L}$ (115 245), total bilirubin $15.7 \mathrm{mg} / \mathrm{dL}(<1.0)$, prothrombin time $8 \%(>70)$, and $\mathrm{NH}_{3} 168 \mu \mathrm{g} / \mathrm{dL}(30 \sim 80)$. Her serological status was as follows: $\mathrm{HBsAg}, \mathrm{HBeAb}$, and IgM $\mathrm{HBcAb}$ were positive, while $\mathrm{HBsAb}$ and $\mathrm{HBeAg}$ were negative. HBV-DNA was present with a level of $4.3 \mathrm{log}$ copies per milliliter $(<2.6)$ by polymerase chain reaction assay. HBV was of genotype B and the precore mutant was $100 \%$. She had no HIV and IgM hepatitis A virus antibodies. An abdominal computed tomography (CT) scan showed atrophic liver. Therefore, a diagnosis of fulminant hepatitis due to the reactivation of HBV from a previously asymptomatic HBV carrier state was made, and lamivudine (a reverse-transcriptase inhibitor of viral DNA polymerase) 
therapy $(150 \mathrm{mg} /$ day $)$ and plasma exchange were immediately performed. Her condition temporarily improved, and liver transplantation was considered. However, her liver function deteriorated and an abdominal CT showed more atrophic liver. She died of liver failure 18 days after admission. A postmortem examination was performed, and the ascites volume was $170 \mathrm{~mL}$. The liver was remarkably atrophied, weighing just $508 \mathrm{~g}$, and more than $80 \%$ of the hepatocytes were necrotic. CD8-positive cytotoxic T lymphocytes had predominantly infiltrated, and amyloid A protein deposition as a result of RA was seen in the hepatic artery (Fig. 1). Vessels in most organs showed amyloid A protein deposition.
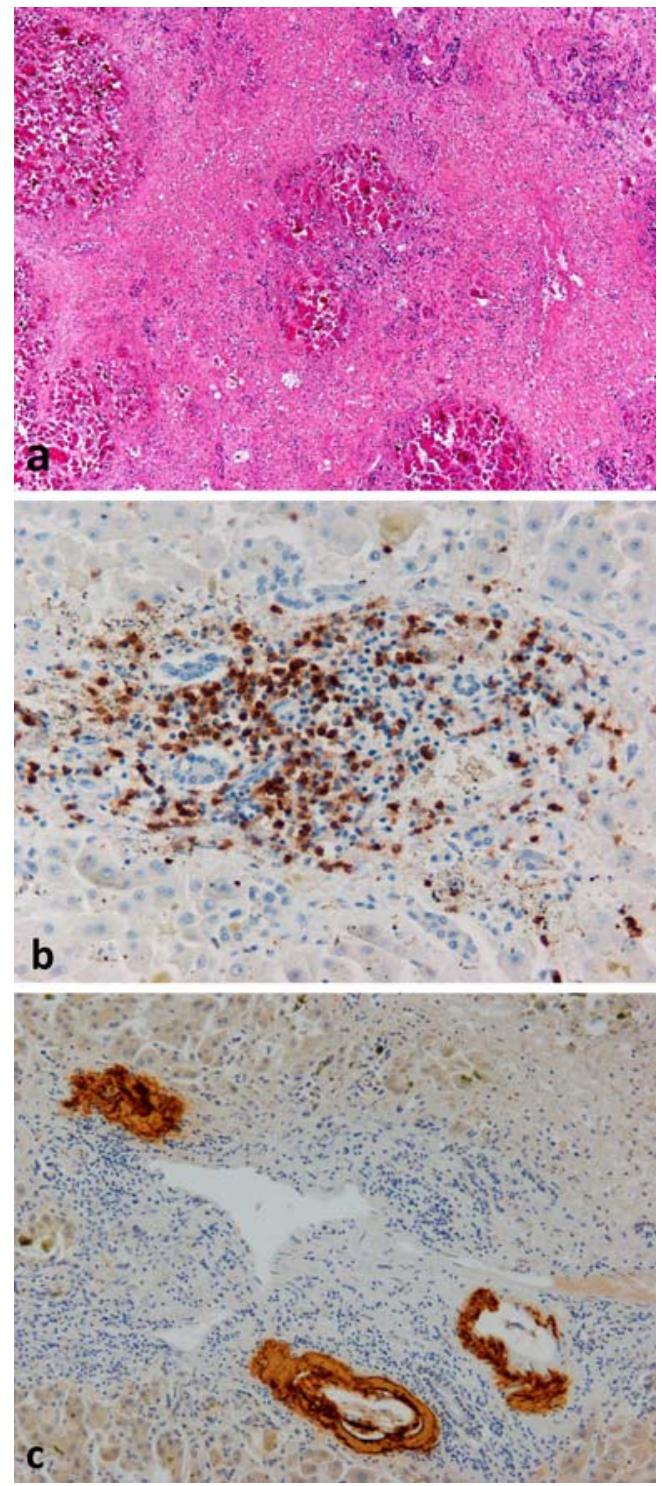

Fig. 1 Liver histology. a Massive hepatocytic necrosis (H\&E stain, $4 \times)$. b Predominantly infiltrated CD8 positive lymphocytes $(20 \times)$. c Amyloid A immunoreactivity of the hepatic artery $(10 \times)$

\section{Discussion}

Our case suggests that infliximab treatment induces HBV precore mutation and the destruction of $\mathrm{HBV}$-infected hepatocytes by $\mathrm{CD} 8$-positive cytotoxic $\mathrm{T}$ lymphocytes. The HBV precore mutation is involved in the pathogenesis of fulminant hepatitis [7], and the reactivation of a precore mutant HBV during infliximab therapy has been reported [8]. TNF- $\alpha$ has antiviral properties by inhibiting the replication of HBV DNA and mediates apoptosis of cytotoxic $\mathrm{T}$ lymphocytes $[9,10]$. TNF- $\alpha$ inhibitors may induce fulminant hepatitis following the reactivation of precore mutant HBV and the proliferation of cytotoxic $\mathrm{T}$ lymphocytes. In addition to infliximab, long-term MTX treatment and subsequent withdrawal may accelerate HBV reactivation. HBV-positive patients are at increased risk of fulminant hepatic failure after withdrawing immunosuppressive drugs such as MTX because of the hepatocytic attack following sudden reaction of the immune system [11].

Preemptive antiviral therapy with lamivudine is recommended as part of infliximab therapy for HBV-positive patients, even if they have normal liver function or an undetectable viral load $[8,12]$. The delayed onset of antiviral therapy in our patient may have been responsible for the fatal outcome. This case shows that infliximab therapy in an HBV-positive patient with RA can lead to fulminant hepatitis, possibly through the reactivation of precore mutant $\mathrm{HBV}$ and the proliferation of cytotoxic $\mathrm{T}$ lymphocytes. In addition, this case illustrates the importance of anti-HBV therapy before starting infliximab administration and withdrawing immunosuppressive drugs.

\section{Disclosures None}

Open Access This article is distributed under the terms of the Creative Commons Attribution Noncommercial License which permits any noncommercial use, distribution, and reproduction in any medium, provided the original author(s) and source are credited.

\section{References}

1. Furst DE, Keystone EC, Fleischmann R, Mease P, Breedveld FC, Smolen JS et al (2010) Updated consensus statement on biological agents for the treatment of rheumatic diseases, 2009. Ann Rheum Dis 69(Suppl 1):i2-i29

2. Ostuni P, Botsios C, Punzi L, Sfriso P, Todesco S (2003) Hepatitis $B$ reactivation in a chronic hepatitis $B$ surface antigen carrier with rheumatoid arthritis treated with infliximab and low dose methotrexate. Ann Rheum Dis 62:686-687

3. Esteve M, Saro C, Gonzalez-Huix F, Suarez F, Forne M, Viver JM (2004) Chronic hepatitis B reactivation following infliximab therapy in Crohn's disease patients: need for primary prophylaxis. Gut 53:1363-1365 
4. Millonig G, Kern M, Ludwiczek O, Nachbaur K, Vogel W (2006) Subfulminat hepatitis B after infliximab in Crohn's disease: need for HBV-screening? World J Gastroenterol 12:974-976

5. Colbert C, Chavarria A, Berkelhammer C (2007) Fulminant hepatic failure in chronic hepatitis B on withdrawal of corticosteroids, azathioprine and infliximab for Crohn's disease. Inflamm Bowel Dis 13:1453-1454

6. Michel M, Duvoux C, Hezode C, Cherqui D (2003) Fulminant hepatitis after infliximab in a patient with hepatitis B virus treated for an adult onset Still's disease. J Rheumatol 30:1624-1625

7. Chen WN, Oon CJ (1999) Human hepatitis B virus mutants: significance of molecular changes. FEBS Lett 453:237-242

8. Wendling D, Auge B, Bettinger D, Lohse A, Huede GL, BressonHadni S, Toussirot E, Miguet JP, Herbein G, Martino VD (2005) Reactivation of a latent precore mutant hepatitis $\mathrm{B}$ virus related chronic hepatitis during infliximab treatment for severe spondyloarthropathy. Ann Rheum Dis 64:788-789
9. Schlaak JF, Tully G, Lohr HF, Gerken G, Meyer Z, Buschenfelde $\mathrm{KH}$ (1999) HBV-specific immune defect in chronic hepatitis B is correlated with a dysregulation of pro- and anti-inflammatory cytokines. Clin Exp Immunol 115:508-514

10. Ando K, Moriyama T, Guidotti LG, Wirth S, Schreiber RD, Schlicht HJ, Huang S, Chisari FV (1993) Mechanisms of class I restricted immunopathology. A transgenic mouse model of fulminant hepatitis. J Exp Med 178:1541-1554

11. Ito S, Nakazono K, Murasawa A, Mita Y, Hata K, Saito N, Kikuchi M, Yoshida K, Nakano M, Gejyo F (2001) Development of fulminant hepatitis B (precore variant mutant type) after the discontinuation of low-dose methotrexate therapy in a rheumatoid arthritis patient. Arthritis Rheum 44:339-342

12. Chung SJ, Kim JK, Park MC, Park YB, Lee SK (2009) Reactivation of hepatitis B viral infection in inactive HBsAg carriers following anti-tumor necrosis factor- $\alpha$ therapy. J Rheumatol 36:2416-2420 